\title{
Challenges MSMEs Face And Benefits In The Adoption Of Open Collaborative Innovation: A Principal Component Approach
}

\author{
Njoku Ola Ama \\ Department of Statistics \\ University of Botswana, Gaborone \\ Francis Nathan Okurut \\ Department of Economics \\ University of Botswana, Gaborone
}

\begin{abstract}
This study investigates the use of open collaborative innovation practices by MSMEs in Botswana and uses the opinions of a stratified sample of 206 MSMEs' owners/managers to identify the benefits and challenges that MSMEs face in engaging in open collaborative innovations to scale up their businesses. The results show that majority of the enterprises $(81.1 \%)$ were not engaged in open collaborative innovations, had owners/managers with first degree qualification or below $(59.7 \%)$, lacked access to financial resources, and had below 5 years of experience $(69.4 \%)$ in running the enterprises. Using the Principal component analysis, the identified benefits are increased financial revenue, improved market strategy, better incentives and improved knowledge; while the challenges are lack of networks, lack of financial support, market demands and previous innovation experiences. The study recommends that there is need for agencies charged with MSME Development in Botswana (LEA, CEDA) to sensitize MSMEs to engage in open collaborative innovation to enhance growth; enterprises should be encouraged to collaborate with universities to bridge the gap in the lack of qualified research experts with $\mathrm{PhD}$; policies to enable the MSMEs access finance for the businesses and protect the intellectual property rights abuse of businesses are imperative; and policies that would protect micro and small enterprises from unnecessary market competition with larger enterprises need to be put in place.
\end{abstract}

Keywords: Open collaborative innovations, MSMEs, benefits, challenges, businesses

\section{INTRODUCTION}

Micro, small, and medium enterprises (MSMEs) represent a very important contributor to the economy of many nations. They are argued to promote inclusive growth through the creation of employment opportunities for the poor especially women (Mead, 1994; Wohlmuth, et al, 2009; Lin \& Lin, 2001; Daniels, 1999). MSMEs are the key to a country's economic growth and their success can help reduce poverty, improve health of families and communities, raise literacy and educational levels, and empower women (Op cit). MSMEs are the dominant form of business organization, representing roughly 95 - 99\% of all companies of which $91.8 \%$ were micro-enterprises (Carnazza, n.d). According to the Organization for Economic Cooperation and Development (OECD), MSMEs represent more than $95 \%$ of enterprises and account for 60 $70 \%$ of the employments in most countries (OECD, 1998) while in US the percentage of enterprises classified as MSMEs is 96 (Robu, 2011; OECD, 2000). MSMEs are the biggest contributors to the gross domestic product and make up over $99 \%$ of all enterprises in all EU countries and in Norway (Airaksinen et al. 2015). The contribution of MSMEs tends to be somewhat lower in manufacturing, although it varies between 40 to 80 per cent of employment in manufacturing (OECD, 2000). In countries like Japan or China, 60\% of GDP comes from MSMEs, in the USA that percentage goes up to 65\%, and in the UE MSMEs generate $52 \%$ of GDP (Ayyagari et al, 2011). In 2010 the degree of employment generated by MSMEs in 
EU was $67 \%$. Micro companies contribute to approximately $30 \%$ of that percentage, small enterprises with approximately $20 \%$ and middle companies with $17 \%$ (Carnazza, n.d; Airaksinen et al. 2015; Edinburg Group, 2012).

In India, MSMEs contribute nearly $45 \%$ to manufacturing and about $40 \%$ to the Indian export sector. Their contribution to the Indian GDP is $8 \%$ and the sector has registered growth rate of $10.8 \%$. MSMEs provide employment to almost 60 million people, and it is the largest source of employment in India, after the agriculture sector (Price water house Coopers Private Limited, 2011). MSMEs brought about 30\% of the total export value in Asia on average in 2007-2012. In the People's Republic of China (PRC), MSMEs accounted for $41.5 \%$ of total export value in 2012, up 6.8\% year-on-year, while in Thailand they made up $28.8 \%$ of total export value with $3.7 \%$ year-on-year growth. MSMEs have the potential to promote international trade and mobilize domestic demand (ADB 2014). MSMEs contributed 59.1\% of nominal gross domestic product (GDP) in Indonesia in 2012. In Thailand, it contributed 37\% of nominal GDP in 2012, and in Malaysia, 32.7\% of real GDP in the same year (Yoshino and Taghizadeh-Hesary, 2016). In Bangladesh, enterprises of less than 100 employees account for $99 \%$ of firms and $58 \%$ of employment. Similarly, in Ecuador, 99\% of all private companies have less than 50 employees and account for $55 \%$ of employment (WBCSD, 2007). According to the International Finance Corporation (IFC), there is a positive relationship between a country's overall level of income and the number of MSMEs per 1,000 people (IFC, 2006).

In Africa there is also boom in small and medium-sized enterprises including microenterprises. More than $90 \%$ of all firms outside the agricultural sector are SMEs and microenterprises, generating a significant portion of GDP. For example, in Morocco, 93\% of industrial firms are MSMEs and account for 38\% of production, 33\% of investment, 30\% of exports and $46 \%$ of employment.These small and growing businesses create around $80 \%$ of the region's employment, establishing a new middle class and fuelling demand for new goods and services (dos Santos, 2015). MSMEs in South Africa account for about $91 \%$ of the formal business entities, contribute to about 51\% of GDP, and provide almost $60 \%$ of employment. The Government of South Africa sees the advancement of Small, Medium and Micro-sized Enterprises (MSMEs) as the catalyst to achieving economic growth, development, job creation, mitigation of poverty, and as an economic empowerment vehicle for previously disadvantaged people (Masarira and Msweli, 2013). It is estimated that MSMEs account for 70 percent of Ghana's gross domestic product (GDP) and 92 percent of its businesses, and 70 percent of the manufacturing sector in Nigeria (Frimpong, 2013). The MSMEs serve as a means for economic diversification through the development of new and unsaturated sectors of the economy. In many African countries MSMEs account for about $50 \%$ of job creation. In Tanzania for example, it is estimated that more than a third of the GDP originates from the MSME sector (Frimpong, 2013; Akugri, 2015).

However, despite this high growth rates, MSMEs are also facing a number of problems. For instance, in India they face suboptimal scale of operation, technological obsolescence, supply chain inefficiencies, increasing domestic and global competition, fund shortages, change in manufacturing strategies and turbulent and uncertain market scenario (Pricewater house Coopers Private Limited, 2011). The main challenges affecting MSMEs in South Africa include lack of management skills, finance, access to bank credit, access to markets, and skills shortage (Masarira and Msweli, 2013). 
Although the level of awareness of MSMEs is remarkable and MSMEs contribute to the development of African economies, yet the growth of MSMEs in Africa faces a number of challenges. They include the lack of access to appropriate capital from both the banking sector and the capital markets. There is a general perception in the financial sector that lending or provision of capital to MSMEs is risky business due to high mortality rates of MSME businesses, suspect management capabilities and skills, poorly prepared business proposals, obscure historical records of the operations of the MSMEs and the lack of reliable collateral or collateral mismatch between type of assets held by MSMEs and type of assets required by banks for collateral (Frimpong, 2013). Yoshino and Taghizadeh-Hesary (2016) outline limited access to finance, lack of a database, low research and development (R\&D) expenditures, undeveloped sales channels, and a low level of financial inclusion as some of the reasons behind the slow growth of MSMEs. Chimucheka and Mandipaka (2015) identified lack of networking opportunities and lack of government support as some of the impediments to the establishment, survival and growth of MSMEs in the Nkonkobe Municipality in Eastern Cape Province of South Africa.

In Botswana, the MSME policy identifies three different categories of micro, small, and medium sized enterprises (MSMEs) (Government of Botswana, 1999) based on the size and annual turnover (see Table 1).

Table 1: Categorization of MSME in Botswana

\begin{tabular}{|l|l|lll|}
\hline Enterprise & Size (employees) & Annual turnover & \\
\hline Micro & $1-5$ (including owner) & $\mathrm{P} 60,000(\$ 7,500)$ \\
\hline Small & $6-24$ & $\mathrm{P} 60,000-\mathrm{P} 1,500,000$ & $(\$ 7,500-\$ 187,500)$ \\
\hline Medium & $25-100$ & $\begin{array}{l}\mathrm{P} 1,500,000 \quad-\quad \mathrm{P} 8,000,000 \quad(\$ 187,500 \\
\$ 1,000,000)\end{array}$ \\
\hline
\end{tabular}

Exchange rate US\$1 = P8; Source: Government of Botswana (2009)

Definitions of MSMEs are different country by country. In some countries the criteria for the categorization is capital, in some countries it is based on the number of employees, and others use a mixed criteria and it varies in each business. In the European Union, the upper limit is 250 employees while in United States MSMEs include firms with fewer than 500 employees. Small firms are those with fewer than 50 employees while micro-enterprises have at most 10 or in some cases five workers (OECD, 2000).

Table 2: Definition of MSMEs based on firm size and percentage of enterprises

\begin{tabular}{|l|l|l|l|l|}
\hline \multirow{2}{*}{$\begin{array}{c}\text { Enterprise } \\
\text { type }\end{array}$} & \multicolumn{2}{|c|}{ United States of America } & \multicolumn{2}{c|}{ European Union } \\
\cline { 2 - 5 } & $\begin{array}{l}\text { Size of } \\
\text { enterprise }\end{array}$ & Percentage (\%) & Size of enterprise & Percentage (\%) \\
\hline Micro & $0-9$ & 50 & Less than 10 & 93 \\
\hline Small & $10-99$ & 38 & $10-49$ & 5.9 \\
\hline Medium & $100-499$ & 8 & $50-249$ & 0.9 \\
\hline Large & 500 or more & 4 & More than 249 & 0.2 \\
\hline
\end{tabular}

Source: OECD/Eurostat database on SME Statistics; OECD (2000)

The MSMEs in Botswana are generally owned by citizens, whereas the larger firms are predominantly foreign owned. Therefore, for this sector to grow, the citizens have to be economically empowered. MSMEs in Botswana account for $50 \%$ of the private sector employment, $32 \%$ of employment (Micro, 14\%; Small, 14\% and Medium, $4 \%$ ) and 15-20\% of the GDP (Jefferis,n.d). Approximately $80 \%$ of the small enterprises cease trading within five years of the establishment phase (Jefferis,n.d; Okurut et al., 2015; Modisane, n.d). The main constraints to the growth of the MSME have been identified to include lack of entrepreneurial and management skills and experience, problems of accessing finance, restrictive regulations, 
lack of market, poor quality products, lack of commitment by promoters on their business and lack of qualified mentors to oversee projects, shortage of business premises especially for small enterprises, and lack technology, innovation and expertise (LEA,2007; BIDPA, 2007; Modisane, n.d; Lall and Peedoly, 2006).

The Government of Botswana has put up structures and institutions to assist the MSMEs. They include:

- Citizen Entrepreneurial Development Agency (CEDA)-provides subsidized credit, along with monitoring, mentoring, business advisory services and training, to selected citizen entrepreneurs (CEDA, 2016);

- The Local Enterprise Authority (LEA)- provides development and support services to the local industry needs of MSMEs, encompassing training, mentoring, business plan finalization, market access facilitation, and facilitation of technology adaptation and adoption (LEA, 2008);

- The Youth Development Fund (YDF) -It caters for out-of-school youth, marginalized youth, unemployed youth and underemployed youth (working youth earning less than P600 monthly) who are citizens of Botswana aged between 18-29 years (Molelu, 2010). The Youth Development Fund is 50 percent grant and 50 percent interest free loan of the total approved amount.

- Young Farmers Fund (YFF)- provides funding to all young people (aged between 18 and 35 years) who are citizens of Botswana or wholly citizen owned companies, wishing to start or expand agricultural projects (Ministry of Finance and Development Planning, 2006).

- Botswana Textile and Small Business Owners Association (BOTSBOA)- develop business linkages between small, medium and large scale entrepreneurs to further entrepreneurial development and growth; creates opportunities for members of the association to interact with Government and other organisations and to facilitate the benefit from Government programmes and incentives; facilitates bulk buying of raw materials for the members to reduce the costs through buying for the association. Membership to BOTSBOA is open to small and medium scale entrepreneurs of all sectors i.e. small business owners (Government of Botswana, 2011).

- Botswana Innovation Hub: The premises of BIH are designed based on four main principles: orientation to high-tech customers, flexibility, ample common-use premises/shared facilities and use of environmentally-friendly technologies; offers tailor-made solutions, with high standards of security and data connections; BIH services are designed to support tenants' competitiveness by allowing them to concentrate on their core business; provides advanced telecommunications infrastructure and services, modern and fully equipped meeting and conference facilities, human resources services, reception and helpdesk, professional facilities management, security and access control, telephone, cleaning, mail, cafeteria \& catering. Additional services as furniture leasing, removal services, travel services, transportation, shipping agent, courier services, short-term legal advisory services are provided. BIH will regularly develop a range of services based on companies' needs and feedback (Government of Botswana, 2011).

- Private sector institutions, which support MSME development, include commercial banks, microfinance institutions and non-government organizations (such as Women in Business Association Botswana [WIBA]). 
Despite the support given to MSMEs by the Government, institutions and the private sectors, the growth of the MSMEs in Botswana has been minimal. One of the areas of support from the institutions has been for MSMEs to establish linkages or collaborate with each other to enhance their growth through innovations. As a strategy for young firms or enterprises to scale up their businesses, open innovation collaboration with larger and established enterprises or firms has been seen to be an important and a valuable option. This is so that younger enterprises are able to access capacity building in financial and organizational management from the larger and established enterprises/firms, while the established firms seeking to improve their external innovation capabilities can take advantage of the different perspectives, approaches and risk outlooks of young firms (World Economic Forum, 2015).

Chesbrough (2006) defined open innovation as the use of "purposeful inflows and outflows of knowledge to accelerate innovation internally while also expanding the markets for the external use of innovation". This model involves strategic, managed exchanges of information. Friedman and Angelus (n.d) defined collaborative innovation as an open innovation strategy that enables consumer packaged goods (CPG) manufacturers and retailers to partner for profit and provide shoppers and consumers with more innovative offerings. Open collaborative innovation allows for the utilization of external ideas from different interinstitutional and transdisciplinary entities, and looks towards the common goal of providing practical solutions to business challenges that arise in a globalized world (Ramirez, 2016). Between 30 and 60 per cent of MSMEs can be characterised as innovative, of which some 10 per cent are technologybased. Innovative MSMEs are more market-driven rather than research-driven, and respond very fast to new opportunities than large firms (OECD, 1998). Open innovation has a wide range of potential opportunities for significantly improving the innovative performance of MSMEs. Open innovation practices, for example, can offer alternative and more viable strategies by which growth-oriented MSMEs can access inter-firm resources at a lower cost, addressing obstacles such as technological and internal financial and human resources that hinder new product development and the ability to enter new markets. Additionally, open innovation can enable greater access to information, technologies and laboratory facilities that could have taken years and require significant R\&D investment to acquire in-house (Wynarczyk, 2014).

A study by the OECD found that only 5-20\% of MSMEs are actively using open innovation approach (Hossain, 2015). Studies on open innovation in MSMEs are also fragmented (Bianchi et al. 2010; Colombo et al. 2014). Some researchers argue that MSMEs can achieve greater benefits from the open innovation than larger firms because of their less bureaucracy, increased willingness to take risks, and faster ability to react to changing environments (Parida et al. 2012). Gassmann et al. (2010) have shown that open innovation is a promising means for MSMEs to overcome their challenges and increase their profitability.

MSMEs face a number of unique challenges to innovate. Abouzeedan et al. (2013) argue that these challenges include scarcity of resources, complexity of scientific field, coordination of the operative functions of the firm, and access to up-to-date scientific excellence. Studies by Van de Vrande et al. (2009) and Saguy (2011) have shown that despite the widespread applications of Open Innovation, MSMEs still struggle with its implementation due to their relatively low level of absorptive capacity, policy and financial constraints, and perceived management challenges (Rahman and Ramos, 2013). Companies that begin to interact with external partners tend to face organizational and cultural issues; negative attitudes to knowledge sharing are the most prevalent among MSMEs and act as the main barrier to the implementation of OI approaches (Yoon et al. 2016). Other challenges faced by MMSMEs which still are related to organisational and cultural issues include: venturing, customer involvement, external networking, research 
and development (R\&D) outsourcing, and external participations (van de Vrande et al. 2009). How these apply to MSMEs in Botswana together with the challenges they encounter in Open Collaborative Innovations (OCI) to improve the growth of the enterprises are not very clear and constitute the crux of this paper.

This study investigates the use of open collaborative innovation practices by MSMEs in Botswana and identifies the challenges that the MSMEs face and the benefits when pursuing a more open approach towards innovation.

\section{METHODOLOGY}

The study covered three cities, namely, Gaborone, Lobatse and Francistown in Botswana and their environs, purposively selected because of concentration of MSMEs. Data were collected from stratified sample of 206 micro, small and medium enterprises (MSMEs) that were interviewed (Table 3). This sample size was determined with the use of Raosoft (2004), a sample size calculator, which shows that a statistically appropriate sample size for a population of 56,450 MSMEs (50, 000 Micro enterprises, 6,000 small enterprises and 450 medium size enterprises) (Sentsho, n.d.) at 95\% confidence interval and allowing an error margin of $5 \%$ is 382 . However, this statistically acceptable sample size was reduced to 206 because of the limited budget for the study.

Table 3: Number of interviewed MSME

\begin{tabular}{|l|c|c|}
\hline Type of enterprise & Number interviewed & Percent \\
\hline Micro & 101 & 49 \\
\hline Small & 80 & 39 \\
\hline Medium & 25 & 12 \\
\hline Total & 206 & 100 \\
\hline
\end{tabular}

Two types of data, qualitative and quantitative data, were collected in the main study from which this paper emanated, through documentary review, focus group discussions/key informant interviews, and MSME survey. The key issues captured from the interviews included: the perceptions of the MSMEs about open collaborative innovations, their experiences with open collaborative innovation initiatives, the benefits and challenges of open collaborative innovations to the enterprises, the cost of these collaborative innovations to the enterprises, what should be done to enhance collaborative innovations and forestall any intellectual property violations in the open collaborative innovations adopted. This paper focusses only on the quantitative results from the survey using questionnaires.

Trained research assistants administered the questionnaires on the owners or managers of the sampled enterprises in their offices. They explained to the participants the purpose of the study, assured them of confidentiality of information supplied and anonymity of individuals participating in the study. The participants were further informed that participation in the study was voluntary; there would be no payment for participation and they could back out of the study any time they desired. Those who accepted to participate in the study were requested to sign a consent form before the interviews were started. The questionnaire used in this study was developed with the help of Oslo Manual (OECD, 2005). At the end of the data collection, 206 fully completed questionnaires were returned.

The study was approved by the University of Botswana Institutional Review Board (IRB) and the Ministry of Trade and Industry research committee before the execution of the study. The 
study covers only a small area of the country. However, information generated will be useful in developing a national study with the excellent methodology.

\section{Characteristics of sampled enterprises}

Table 4 shows the characteristics of the sampled respondents from the different businesses. The male respondents constituted $49 \%$ while 51\% were females. The highest level of education attained by most of the respondents (31.6\%) was secondary, undergraduate degree (19.4\%), postgraduate degree (13.1\%), vocational/technical (18.4\%), professional qualifications (5.8\%), while $8.7 \%$ had primary education. Over half of the respondents (54.9\%) were owner manager, while $13.1 \%$ were owners of businesses, managing directors $(17.5 \%)$ and others (14.5\%). A little less than half or the respondents $(44.7 \%)$ were single (never married), married (37.4\%), separated (4.4\%), divorced (5.3\%), widowed (1.9\%) and cohabiting (6.3\%). Majority of the businesses (66\%) started between the years 2010 and 2016, while 28.2\% started between the years 2000 and 2009, and the rest (5.9\%) started between the years 1980 and 1999. More than half the businesses (52.4\%) were located in rented premises from the private sector. Others were located in own premises (18\%), open market $(11.2 \%)$, industrial site $(3.9 \%)$, free premises offered by friend or relative $(3.9 \%)$, backyard (4.4\%) and premises subsidized by Government/Public Agencies (4.4\%). Close to half of the businesses (47.1\%) were sole proprietorship, limited private company (12.6\%), partnership (12.1\%), and others (24.8\%). The best description of the sectors in which the businesses operate are: Wholesale / Retail Trade (41.3\%), Agriculture (35\%), Manufacturing (8.7\%), Construction (7.3\%) and Transport and Communication (3.9\%). Majority of the businesses (56.3\%) were start-ups. Others originated as linkage to an existing business $(14.6 \%)$, inherited family business $(12.6 \%)$, bought an existing business (9.2\%) and managers buying the business (7.3\%). Most of the businesses could be classified as business in the growth stage $(45.6 \%)$ followed by those in the start-up stage $(24.3 \%)$, and those in the maturity stage (17.5\%). The majority of businesses (81.6\%) were formal. Most of the business owners/managers (69.4\%) had between 0 and 5 completed years of experience while 19.4\% had between 6 and 10 completed years of experience. The majority of them $(81.1 \%)$ had not been involved in any open collaborative innovations. About half of the enterprises (49\%) had only between 1 and 5 employees including the owner (Micro enterprises) while 38.8\% had between 6 and 24 employees (Small enterprises) and 12.1\% had between 25 and 99 employees (Medium enterprises). The average number of years of existence of businesses is 6.6 . 
Table 4: Characteristics of the sampled MSME owners/managers

\begin{tabular}{|c|c|c|c|}
\hline \multicolumn{2}{|c|}{ Characteristics of respondents } & Number & $\%$ \\
\hline \multirow{2}{*}{ Sex of respondent } & Male & 101 & 49.0 \\
\hline & Female & 105 & 51.0 \\
\hline \multirow{7}{*}{$\begin{array}{l}\text { Highest Level of } \\
\text { Education }\end{array}$} & Primary level & 18 & 8.7 \\
\hline & Secondary level & 65 & 31.6 \\
\hline & Undergraduate degree & 40 & 19.4 \\
\hline & Postgraduate degree & 27 & 13.1 \\
\hline & $\begin{array}{l}\text { Vocational/Technical Professional } \\
\text { qualification }\end{array}$ & 38 & 18.4 \\
\hline & Professional qualification & 12 & 5.8 \\
\hline & Non Formal Education & 6 & 2.9 \\
\hline \multirow{11}{*}{$\begin{array}{l}\text { Position/role in the } \\
\text { enterprise }\end{array}$} & Owner manager & 113 & 54.9 \\
\hline & Owner & 27 & 13.1 \\
\hline & Managing director & 36 & 17.5 \\
\hline & Accountant & 5 & 2.4 \\
\hline & Shop attendant & 1 & 0.5 \\
\hline & Human resource admin officer & 1 & 0.5 \\
\hline & Sales and marketing & 12 & 5.8 \\
\hline & Supervisor & 4 & 1.9 \\
\hline & HR manager & 3 & 1.5 \\
\hline & Manager & 2 & 1.0 \\
\hline & Sales representative & 2 & 1.0 \\
\hline \multirow{6}{*}{ Marital status } & Single & 92 & 44.7 \\
\hline & Married & 77 & 37.4 \\
\hline & Separated & 9 & 4.4 \\
\hline & Widow & 4 & 1.9 \\
\hline & Divorced & 11 & 5.3 \\
\hline & Cohabiting & 13 & 6.3 \\
\hline \multirow{4}{*}{ Year the business started } & $1980-1989$ & 3 & 1.5 \\
\hline & 1990-1999 & 9 & 4.4 \\
\hline & $2000-2009$ & 58 & 28.2 \\
\hline & 2010-date & 136 & 66 \\
\hline \multirow{3}{*}{ District } & Gaborone & 90 & 43.7 \\
\hline & Lobatse & 45 & 21.8 \\
\hline & Francistown & 71 & 34.5 \\
\hline \multirow{8}{*}{$\begin{array}{l}\text { Physical Location of } \\
\text { Enterprise }\end{array}$} & $\begin{array}{l}\text { Backyard } \\
\text { Premises subsidized by }\end{array}$ & 9 & 4.4 \\
\hline & Government/Public Agencies & 9 & 4.4 \\
\hline & Own premises & 37 & 18.0 \\
\hline & Rented premises from private sector & 108 & 52.4 \\
\hline & Free Premises offered by friend/relative & 8 & 3.9 \\
\hline & Open Market & 23 & 11.2 \\
\hline & Industrial site & 8 & 3.9 \\
\hline & Mobile & 4 & 1.9 \\
\hline Legal status of your & Sole Proprietorship & 97 & 47.1 \\
\hline
\end{tabular}




\begin{tabular}{|c|c|c|c|}
\hline \multirow[t]{6}{*}{ registered business entity } & Partnership & 25 & 12.1 \\
\hline & Cooperative & 2 & 1.0 \\
\hline & Limited Private Co. & 26 & 12.6 \\
\hline & Society/Group & 5 & 2.4 \\
\hline & Registered Businesses & 41 & 19.9 \\
\hline & Auto Mechanic & 10 & 4.9 \\
\hline \multirow{6}{*}{$\begin{array}{l}\text { Best description of the } \\
\text { sector in which you } \\
\text { operate }\end{array}$} & Manufacturing & 18 & 8.7 \\
\hline & Transport and Communication & 8 & 3.9 \\
\hline & Construction Services & 15 & 7.3 \\
\hline & Wholesale / Retail Trade & 85 & 41.3 \\
\hline & Agriculture & 72 & 35.0 \\
\hline & Others & 8 & 3.9 \\
\hline \multirow{5}{*}{ How business originated } & Linkage to an existing business & 30 & 14.6 \\
\hline & Inherited family business & 26 & 12.6 \\
\hline & Bought an existing business & 19 & 9.2 \\
\hline & Managers buying the business ) & 15 & 7.3 \\
\hline & Completely new start-up & 116 & 56.3 \\
\hline \multirow{5}{*}{$\begin{array}{l}\text { How would you classify } \\
\text { your business growth }\end{array}$} & A business in the Seed stage & 10 & 4.9 \\
\hline & A business in the Start-up stage & 50 & 24.3 \\
\hline & A business in the Growth stage & 94 & 45.6 \\
\hline & A business in the Maturity stage & 36 & 17.5 \\
\hline & A business in the Decline stage & 16 & 7.8 \\
\hline \multirow{2}{*}{$\begin{array}{l}\text { Classification of your } \\
\text { business }\end{array}$} & Formal & 168 & 81.6 \\
\hline & Informal & 38 & 18.4 \\
\hline \multirow{2}{*}{$\begin{array}{l}\text { Firm has been engaged in } \\
\text { some form of open } \\
\text { collaborations }\end{array}$} & Yes & 39 & 18.9 \\
\hline & No & 167 & 81.1 \\
\hline \multirow{4}{*}{$\begin{array}{l}\text { Years of experience in } \\
\text { business }\end{array}$} & $0-5$ & 143 & 69.4 \\
\hline & $6-10$ & 40 & 19.4 \\
\hline & $11-15$ & 12 & 5.8 \\
\hline & 16 and over & 11 & 5.3 \\
\hline \multirow{3}{*}{$\begin{array}{l}\text { Number of employees in } \\
\text { your company }\end{array}$} & $1-5$ & 101 & 49.0 \\
\hline & $6-24$ & 80 & 38.9 \\
\hline & $25-99$ & 25 & 12.1 \\
\hline
\end{tabular}

\section{Engagement in Open Collaborative Innovation}

On the question as to whether the enterprises have ever been engaged in any form of open collaborative innovation, only $18.9 \%(n=39)$ were in the affirmative while $81.1 \%(n=167)$ had never engaged in open collaborative innovation. Of the enterprises that had been engaged in open collaborative innovation, $44 \%$ were formal enterprises collaborating with other formal enterprises; 33\% were informal collaborating with formal enterprises while 23\% were informal enterprises collaborating with other informal enterprises (Figure 1). 


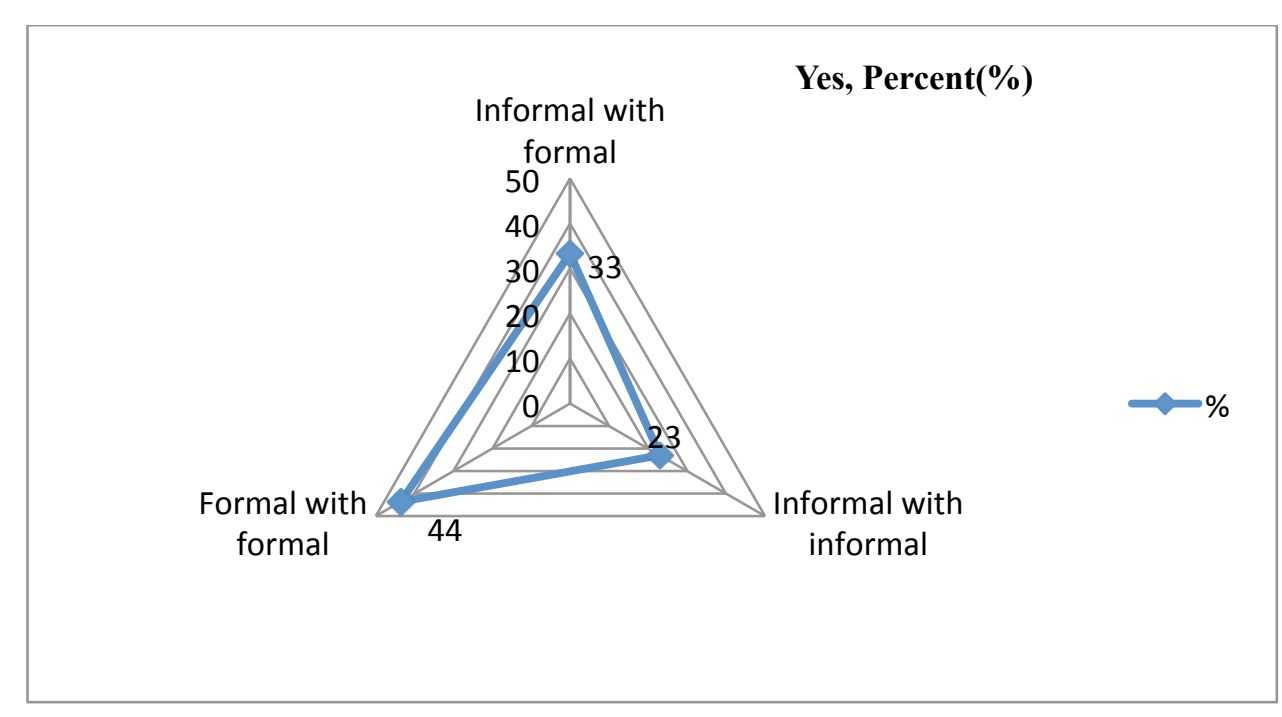

Figure 1: Form of open collaborative innovation

\section{Benefits of the open collaborative innovation to enterprises (scale up)}

The benefits of OCI to enterprises in this study were assessed by the responses of the enterprises to 23 suggested options of possible benefits in terms of scaling up their businesses on a five point Likert scale of $1=$ strongly disagree, $2=$ disagree, $3=$ neither agree nor disagree, $4=$ agree and $5=$ strongly agree.

The responses were subjected to Principal Component Analysis, a data reduction process, so as to determine the variables that best describe the benefits of OCI in scaling up the enterprises based on the components that explain the highest percentage of total variation in the variables. Table 5 shows the four components that best describes the benefits, namely, increased financial revenue which explains over half (58.3\%) of the total variation in all the variables and heavily loaded on financial (e.g. increased valuation)(0.841), agility to adopt more quickly to market changes (0.813), business (increased revenue)(0.801), investment (0.789), access to key contacts (0.743), increased visibility and enhanced publicity or reputation (0.678), relationship with experts in scaling up (0.61), access to markets (0.54). The second component which explains $8.8 \%$ of the total variation is improved market strategy and is heavily loaded on increased profit (0.836), improved strategy on markets $(0.835)$, new products and services (0.742), provision of tools and training staff $(0.6)$, increase in shareholder value $(0.571)$, and creation of strategic plans (0.559). The third component, best described as better incentives, explains $7.7 \%$ of the total variation and is loaded heavily on recognition and reward of achievement (0.795), communication effectiveness (0.777), motivation of staff (0.756), and improved hiring process to find best professionals to take the business to next level (0.692). The fourth component is improved knowledge which explains $6 \%$ of the total variation and heavily loaded on gaining market knowledge (0.86), business development (entering new markets or gaining new customers) (0.835), start-ups may bring fresh thinking to help solve core business problems (0.657), increased number of skilled employees (0.552). The four components explain $80.8 \%$ of the total variance. 
Table 5: Principal Components that best describes the benefits of OCI to enterprises

\begin{tabular}{|c|c|c|c|c|}
\hline \multirow[b]{2}{*}{ Benefits of open collaborative innovations } & \multicolumn{4}{|c|}{ Component } \\
\hline & $\begin{array}{l}\text { Increased } \\
\text { financial } \\
\text { revenue (1) }\end{array}$ & $\begin{array}{l}\text { Improved } \\
\text { market } \\
\text { strategy } \\
(2)\end{array}$ & $\begin{array}{l}\text { Better } \\
\text { incentives } \\
\text { (3) }\end{array}$ & $\begin{array}{l}\text { Improved } \\
\text { knowledge } \\
(4)\end{array}$ \\
\hline Financial (e.g. increased valuation) & 0.841 & & & \\
\hline Agility to adapt more quickly to market changes & 0.813 & & & \\
\hline Business (increased revenue ) & 0.801 & & & \\
\hline Investment & 0.789 & & & \\
\hline Access to key contacts & 0.743 & & & \\
\hline Visibility and enhanced publicity or reputation & 0.678 & & & \\
\hline Relationship with experts in scaling up & 0.61 & & & \\
\hline Access to new markets & 0.54 & & & \\
\hline Increased profit & & 0.836 & & \\
\hline Improved strategy on markets & & 0.835 & & \\
\hline New products and services & & 0.742 & & \\
\hline Provision of tools and training to staff & & 0.600 & & \\
\hline Increase in shareholder value & & 0.571 & & \\
\hline Creation of strategic plans & & 0.559 & & \\
\hline Alliances with other firms or with universities & & 0.547 & & \\
\hline Recognition and reward of achievement & & & 0.795 & \\
\hline Communication effectiveness & & & 0.777 & \\
\hline $\begin{array}{l}\text { Motivation of staff } \\
\text { Improved hiring process to find best professionals to } \\
\text { take the business to next level }\end{array}$ & & & $\begin{array}{l}0.756 \\
0.692\end{array}$ & \\
\hline $\begin{array}{l}\text { Gaining market knowledge } \\
\text { Business development (entering new markets or } \\
\text { gaining new customers), } \\
\text { Start-ups may bring fresh thinking to help solve core } \\
\text { business problems }\end{array}$ & & & & $\begin{array}{l}0.860 \\
0.835 \\
0.657\end{array}$ \\
\hline Increased number of skilled employees & & & & 0.552 \\
\hline
\end{tabular}

Table 6 gives the models for the four principal components. The first principal component is positively correlated with business (increased revenue) $\left(\mathrm{X}_{21}\right)$, investment $\left(\mathrm{X}_{20}\right)$, financial (e.g. increased valuation $)\left(\mathrm{X}_{21}\right)$, agility to adapt more quickly to market changes, visibility and enhanced publicity or reputation $\left(\mathrm{X}_{22}\right)$ and relationship with experts in scaling up $\left(\mathrm{X}_{23}\right)$. The second component is positively correlated with increased profit $\left(\mathrm{X}_{11}\right)$, improved strategy on markets $\left(\mathrm{X}_{12}\right)$, new products and services $\left(\mathrm{X}_{1}\right)$ while the third component is positively correlated with improved hiring process to find best professionals to take the business to next level $\left(\mathrm{X}_{3}\right)$, motivation of staff $\left(\mathrm{X}_{4}\right)$, communication effectiveness ( $\mathrm{X}_{5}$ )and recognition and reward of achievement $\left(\mathrm{X}_{6}\right)$. The fourth component is positively correlated with gaining market knowledge $\left(\mathrm{X}_{16}\right)$, business development (entering new markets or gaining new customers) $\left(\mathrm{X}_{17}\right)$, start-ups may bring fresh thinking to help solve core business problems $\left(\mathrm{X}_{18}\right)$, and increased number of skilled employees $\left(\mathrm{X}_{2}\right)$. 


\begin{tabular}{|c|c|c|c|c|c|}
\hline \multirow[b]{2}{*}{ Variables } & \multicolumn{4}{|c|}{ Principal Component } & \multirow[t]{2}{*}{$\begin{array}{l}\text { Variable } \\
\text { names }\end{array}$} \\
\hline & 1 & 2 & 3 & 4 & \\
\hline New products and services & -0.17 & 0.32 & -0.14 & 0.15 & $\mathrm{X}_{1}$ \\
\hline $\begin{array}{l}\text { Increased number of skilled employees } \\
\text { Improved hiring process to find best professionals to take the } \\
\text { business to next level }\end{array}$ & $\begin{array}{l}-0.16 \\
-0.13\end{array}$ & $\begin{array}{l}-0.05 \\
-0.04\end{array}$ & $\begin{array}{l}0.14 \\
0.25\end{array}$ & 0.24 & $\begin{array}{l}\mathrm{X}_{2} \\
\mathrm{X}_{3}\end{array}$ \\
\hline Motivation of staff & -0.02 & -0.11 & 0.27 & -0.02 & $\mathrm{X}_{4}$ \\
\hline Communication effectiveness & -0.05 & -0.06 & 0.29 & -0.04 & $\mathrm{X}_{5}$ \\
\hline Recognition and reward of achievement & -0.09 & -0.11 & 0.34 & -0.02 & $\mathrm{X}_{6}$ \\
\hline Provision of tools and training to staff & -0.25 & 0.18 & 0.22 & 0.07 & $\mathrm{X}_{7}$ \\
\hline Creation of strategic plans & -0.08 & 0.15 & 0.05 & 0.04 & $\mathrm{X}_{8}$ \\
\hline Increase in shareholder value & 0.08 & 0.15 & -0.01 & -0.13 & $\mathrm{X}_{9}$ \\
\hline Relationship with experts in scaling up & 0.12 & -0.01 & 0.12 & -0.17 & $\mathrm{X}_{10}$ \\
\hline Increased profit & -0.01 & 0.30 & -0.02 & -0.17 & $\mathrm{X}_{11}$ \\
\hline Improved strategy on markets & 0.03 & 0.30 & -0.11 & -0.13 & $\mathrm{X}_{12}$ \\
\hline Alliances with other firms or with universities & 0.06 & 0.13 & -0.07 & -0.01 & $\mathrm{X}_{13}$ \\
\hline Visibility and enhanced publicity or reputation & 0.12 & -0.02 & -0.05 & 0.06 & $\mathrm{X}_{14}$ \\
\hline Access to new markets & 0.08 & 0.13 & -0.17 & 0.07 & $\mathrm{X}_{15}$ \\
\hline $\begin{array}{l}\text { Gaining market knowledge } \\
\text { Business development (entering new markets or gaining new } \\
\text { customers), } \\
\text { Start-ups may bring fresh thinking to help solve core business } \\
\text { problems }\end{array}$ & $\begin{array}{r}-0.09 \\
0.00 \\
0.03\end{array}$ & $\begin{array}{l}-0.02 \\
-0.10\end{array}$ & $\begin{array}{l}-0.04 \\
-0.09 \\
-0.01\end{array}$ & $\begin{array}{l}0.34 \\
0.32 \\
0.20\end{array}$ & $\begin{array}{l}\mathrm{X}_{16} \\
\mathrm{X}_{17} \\
\mathrm{X}_{18}\end{array}$ \\
\hline Access to key contacts & 0.16 & -0.03 & -0.05 & 0.02 & $\mathrm{X}_{19}$ \\
\hline Investment & 0.22 & -0.07 & -0.13 & 0.02 & $\mathrm{X}_{20}$ \\
\hline Financial (e.g. increased valuation) & 0.22 & -0.09 & -0.03 & -0.04 & $\mathrm{X}_{21}$ \\
\hline Business (increased revenue ) & 0.23 & -0.06 & -0.02 & -0.11 & $\mathrm{X}_{22}$ \\
\hline Agility to adapt more quickly to market changes & 0.21 & -0.08 & -0.04 & -0.04 & $\mathrm{X}_{23}$ \\
\hline
\end{tabular}

\section{Challenges faced by the MSMEs in embracing open collaborative innovations.}

The enterprises were asked to rate how important some defined 13 variables were to them in hampering their innovation activities on a four point scale of $1=$ Not used; $2=$ Low and $3=$ Medium and $4=$ High. To underscore the most important factors hindering embracing open collaborative innovation, the variables were subjected to a Principal Component analysis (PCA) and four factors, namely, networking, financial support, market demands and previous innovation experiences with the highest eigen values of 4.94, 1.55, 1.34 and 1.12, respectively, were identified as challenges to open collaborative innovations. These components account for $68.9 \%$ of the total variation in the observed variables (Table 7).

\section{Networking (F1)}

This component was highly loaded on six variables: Difficulty in finding cooperation partners for innovation with component loading 0.785, which represents the strength of the relationship between the variable and the component; Lack of information on technology (0.716); Violation of intellectual property rights (0.636); High cost of these collaborative innovations to the enterprises (0.597); Free-rider syndrome (0.577) and Lack of qualified personnel (0.517). The component explained $38.02 \%$ of the total variance. 


\section{Financial Support (F2)}

This component was heavily loaded on three variables: Lack of finance from other sources outside the enterprise with component loading 0.876 , Lack of funds within your enterprise or group (0.820) and Lack of information on markets (0.638). This factor explained $11.95 \%$ of the total variance.

\section{Market demands (F3)}

This component is heavily loaded on two variables: Market dominated by established enterprises with component loading 0.825 and uncertain demand for innovative goods or services (0.763). The component explained $10.34 \%$ of the total variance.

\section{Previous innovation experience (F4)}

This component is loaded highly on two variables: No need because there are no demands for innovation with component loading 0.864 and No need due to prior innovations (0.669). The factor explained $8.57 \%$ of the total variance.

The Kaiser-Meyer-Olkin Measure of Sampling Adequacy with value of approximately 0.7 (good) shows that we should be confident that the sample size is adequate for PCA. The Bartlett's measure tests the null hypothesis that the original correlation matrix is an identity matrix against the alternative that it is not an identity matrix. Thus they are some relationships between the variables that are in the analysis. The Bartlett's test is significant $(p<0.01)$ showing that the variables are highly correlated lending themselves for PCA.

Table 7: Principal Components that best describe the challenges to open collaborative innovation

\begin{tabular}{|c|c|c|c|c|}
\hline \multirow[b]{2}{*}{ Variables } & \multicolumn{4}{|c|}{ Factors } \\
\hline & Networking & $\begin{array}{l}\text { Financial } \\
\text { support }\end{array}$ & $\begin{array}{l}\text { Market } \\
\text { demands }\end{array}$ & $\begin{array}{l}\text { Previous } \\
\text { innovation } \\
\text { experience }\end{array}$ \\
\hline $\begin{array}{l}\text { Difficulty in finding cooperation partners for } \\
\text { innovation }\end{array}$ & 0.785 & & & \\
\hline Lack of information on technology & 0.716 & & & \\
\hline $\begin{array}{l}\text { Violation of intellectual property rights } \\
\text { High cost of these collaborative innovations to the } \\
\text { enterprises }\end{array}$ & $\begin{array}{l}0.636 \\
0.597\end{array}$ & & & \\
\hline Free-rider syndrome & 0.577 & & & \\
\hline $\begin{array}{l}\text { Lack of qualified personnel } \\
\text { Lack of finance from sources outside your } \\
\text { enterprise }\end{array}$ & 0.517 & 0.876 & & \\
\hline Lack of funds within your enterprise or group & & 0.820 & & \\
\hline Lack of information on markets & & 0.638 & & \\
\hline $\begin{array}{l}\text { Market dominated by established enterprises } \\
\text { Uncertain demand for innovative goods or } \\
\text { services }\end{array}$ & & & $\begin{array}{l}0.825 \\
0.763\end{array}$ & \\
\hline No need because of no demands for innovation & & & & 0.864 \\
\hline No need due to prior innovations & & & & 0.669 \\
\hline $\begin{array}{l}\text { \% Variance explained } \\
\text { Kaiser-Meyer-Olkin Measure of Sampling } \\
\text { Adequacy. }\end{array}$ & 38.02 & 11.95 & $\begin{array}{r}10.34 \\
0.7\end{array}$ & 8.57 \\
\hline Bartlett's Test of Sphericity & & & $\mathrm{df}=78$ & sig. $=0.000$ \\
\hline
\end{tabular}


Table 8 shows the models for the four components (factors). The factor score or beta coefficient indicates the level of relationship between a component and the various variables. Thus in the first equation (component 1), the networking factor, is positively correlated with difficulty in finding cooperation partners for innovation $\left(X_{8}\right)$, violation of intellectual property rights $\left(X_{13}\right)$, lack of information on technology $\left(X_{6}\right)$ and high cost of these collaborative innovations to the enterprises $\left(X_{3}\right)$. It has the highest regression weight of 0.373 on the variable $\mathrm{X}_{8}$ (difficulty in finding cooperation partners for innovation). The second component (Financial support) is positively correlated with lack of funds within the enterprise or group ( $\left.X_{1}\right)$, lack of finance from sources outside the enterprise $\left(X_{2}\right)$ and lack of information on markets $\left(X_{7}\right)$. The market demands component is positively correlated with Uncertain demand for innovative goods or services $\left(X_{10}\right)$ and Market dominated by established enterprises $\left(X_{9}\right)$ while the fourth component, previous innovation experience, is highly positively correlated with no need due to prior innovations $\left(X_{11}\right)$ and no need because of no demands for innovation $\left(X_{12}\right)$

Table 8: Principal component models for the different components

\begin{tabular}{|c|c|c|c|c|c|}
\hline \multirow[b]{2}{*}{ Variables } & \multicolumn{4}{|c|}{ Factors } & \multirow[t]{2}{*}{$\begin{array}{l}\text { Variable } \\
\text { names }\end{array}$} \\
\hline & Networking & $\begin{array}{l}\text { Financial } \\
\text { support }\end{array}$ & $\begin{array}{l}\text { Market } \\
\text { demands }\end{array}$ & $\begin{array}{l}\text { Previous } \\
\text { Innovation } \\
\text { experience }\end{array}$ & \\
\hline \multirow{3}{*}{$\begin{array}{l}\text { Lack of funds within the enterprise or group } \\
\text { Lack of finance from sources outside your } \\
\text { enterprise } \\
\text { High cost of these collaborative innovations } \\
\text { to the enterprises }\end{array}$} & -0.195 & 0.349 & 0.074 & 0.105 & $X_{1}$ \\
\hline & -0.101 & 0.414 & -0.086 & -0.088 & $X_{2}$ \\
\hline & 0.232 & 0.119 & -0.251 & -0.015 & $X_{3}$ \\
\hline Free-rider syndrome & 0.163 & 0.089 & -0.101 & 0.114 & $X_{4}$ \\
\hline Lack of qualified personnel & 0.142 & 0.082 & 0.016 & -0.026 & $X_{5}$ \\
\hline Lack of information on technology & 0.251 & 0.058 & -0.024 & -0.105 & $X_{6}$ \\
\hline \multirow{4}{*}{$\begin{array}{l}\text { Lack of information on markets } \\
\text { Difficulty in finding cooperation partners for } \\
\text { innovation } \\
\text { Market dominated by established } \\
\text { enterprises } \\
\text { Uncertain demand for innovative goods or } \\
\text { services }\end{array}$} & 0.051 & 0.197 & 0.109 & -0.122 & $X_{7}$ \\
\hline & 0.373 & -0.187 & 0.057 & -0.167 & $X_{8}$ \\
\hline & -0.081 & -0.059 & 0.500 & 0.01 & $X_{9}$ \\
\hline & -0.043 & -0.029 & 0.464 & -0.107 & $X_{10}$ \\
\hline \multirow{2}{*}{$\begin{array}{l}\text { No need due to prior innovations } \\
\text { No need because of no demands for } \\
\text { innovation }\end{array}$} & 0.104 & 0.031 & -0.274 & 0.497 & $X_{11}$ \\
\hline & -0.171 & -0.079 & 0.101 & 0.683 & $X_{12}$ \\
\hline Violation of intellectual property rights & 0.282 & -0.306 & 0.169 & 0.086 & $X_{13}$ \\
\hline
\end{tabular}

\section{DISCUSSION OF THE RESULTS}

This paper investigated the use of open collaborative innovation by MSMEs in Botswana and identified the benefits that studied MSMEs derived in adopting the open collaborative innovations and the challenges they face. The study revealed that majority of the businesses (69.4\%) did not have experienced owners /managers running them; had only between 1 and 5 employees (49\%), with average age of existence, 6.6 years; and had not been involved in any 
open collaborative innovations (81.1\%). Close to half $(47.1 \%)$ of the businesses were sole proprietorship and were in their growth stage (business is growing steadily and sales are increasing) (45.6\%) while $56.3 \%$ of them originated as new start up. The findings of the study are in line with those of Hossain (2015) that stated that only between 5\% and 20\% of MSMEs are adopting open innovations in the OECD countries. van de Vrande et al. (2009) and Teirlinck and Spithoven (2013) found that the smaller the size of an SME, the less the degree of collaboration and medium-sized firms have lower involvement in R\&D outsourcing than the smaller enterprises. However, the small sizes of the enterprises can be capitalized on to enhance open collaborative innovations since the enterprises can be more homogeneous and therefore unlikely to be affected by bureaucratic manipulations. The enterprises are also more likely to have strong desires to take risks which are essential ingredients in business expansion (Parida et al. 2012).

The study revealed that $60 \%$ of the enterprises' owners/managers had a first degree qualification or below. This explains to some degree why most of the enterprises studied were not engaged in open collaborative innovations. Studies have shown that the urge to engage in research cooperation is positively associated with the number of $\mathrm{PhD}$ holders among the research managers and R\&D experts (Teirlinck and Spithoven, 2013) and also, the craving to outsource increases with the formal qualification level of the R\&D personnel and with $R \& D$ training (Op cit).

The youthful nature of the businesses, and with owners/managers who are inexperienced are likely to have affected the desire of the enterprises to get engaged in open collaborative innovation. Rahman and Ramos, (2013) advocated that MSMEs with these characteristics are bound to have relatively low level of absorptive capacity, policy and financial constraints, and perceived management challenges to be effectively engaged in open collaborative innovations and to realize its benefits (Van de Vrande et al., 2009; Saguy, 2011). Open collaborative innovation requires that managers/owners must be able to identify the critical knowledge associated with every step of their enterprises' innovative processes and be able to institute processes for integrating knowledge into their collaborative efforts (Gassmann et al, 2010). This move requires experience and necessary skills which might be lacking in the youthful enterprises. It is important, therefore, to have leadership of enterprises with absorptive capacity to drive several organizational changes, including the institution of an effective knowledge management strategy. In their paper, Tushman and Nadler (1986) identified that visionary leadership is an important factor that affect whether an organization realizes benefits from innovation. Ashurst, Freer, Ekdahl, and Gibbons (2012) emphasized that organizations can gain competitive advantage not only by managing effectively for today, but at the same time by creating innovation for tomorrow.

The main challenges that the studied MSMEs had are categorized as: networking deficiencies, lack of financial support, inability to meet the market demands and unhealthy previous innovation experiences. The enterprises had difficulties in finding cooperation partners for innovation, lacked information on appropriate technologies and found collaborative innovation very costly to embark on. They found the markets were dominated by the established enterprises with uncertain demand for their innovative goods or services. About one out of every four businesses is at the start-up stage making competition for the market extremely difficult. Most of the businesses could not attract resources from financial houses but relied on internal resources. For some of the enterprises, previous experiences at collaboration with other enterprises have been very awful. These findings are in line with previous studies. For instance, Abouzeedan et al. (2013) identified the challenges facing MSMEs to include scarcity of resources, complexity of the scientific field, coordination of the 
operative functions of the firm, and access to up-to-date scientific excellence. Christensen et al. (2005) highlighted that open innovation sometimes incurs high transaction costs. Wynarczyk (2013) argued that to remain competitive locally and internationally, MSMEs are highly dependent on R\&D capacity, managerial structure and competencies, open innovation practices and the ability of the enterprises to attract government grants for R\&D and technological development.

Notwithstanding the above challenges that MSMEs have, most of the few enterprises that were involved in OCI still realized some benefits which included: increased financial benefits, businesses having added value, experienced increased agility to adapt more quickly to market changes, realized increased revenue and investments, more access to key contacts, increased visibility and enhanced publicity or reputation in the public domain with improved relationship with experts on how businesses can be scaled up. Improvement in market strategy, better business incentives and improved knowledge of business management principles were some other benefits realized. These results are in line with Wynarczyk (2014) who showed that open innovation can enable greater access to information, technologies and laboratory facilities that could have taken years and which require significant R\&D investment to acquire in-house. Although Lee et al. (2009) found that the open innovation is not an attractive option especially for enterprises at the early-stage (start-ups) because they do not have adequate capabilities regarding R\&D investment, Lee et al. (2010) showed that open innovation has high potential for MSMEs, including micro enterprises.

It is, therefore, imperative that if the MSMEs are equipped with appropriate resources such as finances for the businesses, appropriate information on innovation practices and technology, higher education and appropriate IP environment, the challenges of small size and inability to conduct research and participate in development can be overcome. Enterprises owners/managers need higher education and training which encourage and appreciate creativity, critical thinking, self-discipline, self-motivation, desire for knowledge and life-long learning, openness, and cooperation to sensitize MSMEs towards open innovation practices and establishments of networks to enhance productivity of the businesses through launching products and services.

\section{RECOMMENDATIONS}

The study, therefore, recommend as follows:

> There is need for agencies charged with MSME Development in Botswana (LEA, CEDA) to sensitize MSMEs to engage in open collaborative innovation to enhance growth.

$>$ Owner/managers of MSMEs need to be trained in management of enterprises which include knowledge of government regulations, new technologies and innovation parameters, customer responsiveness, IP rights and practices, and information on new markets.

$>$ Enterprises should be encouraged to collaborate with universities to bridge the gap in the lack of qualified research experts with $\mathrm{PhD}$ to enhance their $\mathrm{R} \& \mathrm{D}$ needs for innovation.

$>$ Policies to enable the MSMEs access finance for the businesses and protect the intellectual property rights abuse of businesses are imperative.

$>$ Policies that would protect micro and small enterprises from unnecessary market competition with larger enterprises need to be put in place. 


\section{ACKNOWLEDGEMENT}

The authors wish to thank the Open AIR network and acknowledge the support of University of Cape Town (UCT), its partners and the Project's funders, namely, the UK Government's Department for International Development, the International Development Research Centre (IDRC), Canada, and the Social Sciences and Humanities Research Council of Canada for the financial support to carry out the study The views expressed in this work are those of the authors and do not necessarily represent those of the research funders.

\section{References}

Abouzeedan, A, Klofsten, M, \& Hedner, T. (2013). Internetization Management as a Facilitator for Managing Innovation in High-Technology Smaller Firms. Global Business Review, 14(1), 121-136.

Akugri, M.S., Bagah, D.A. and. Wulifan J.K.(2015) The Contributions of Small and Medium Scale Enterprises to Economic Growth: A Cross-Sectional study of Zebilla in the Bawku West District of Northern Ghana. European Journal of Business and Management ISSN 2222-1905 (Paper) ISSN 2222-2839 (Online) Vol.7, No.9, 262-274

Airaksinen, A., Luomaranta, H., Alajääskö, P., and Roodhuijzen A. (2015) . Statistics on small and medium-sized enterprises: Dependent and independent MSMEs and large enterprises. Available at http://ec.europa.eu/eurostat/statistics-explained/index.php/Statistics_on_small_and_medium-sized_enterprises. Accessed 17 April 2017

Ayyagari, M., Demirgüç-Kunt, A. and Maksimovic, V. (2011), Small vs. Young Firms across The World Contribution to Employment, Job Creation, and Growth, Policy Research Working Paper 5631 (The World Bank Development Research Group)

Ashurst, C., Freer, A., Ekdahl, J., \& Gibbons, C. (2012). Exploring IT-enabled innovation: A new paradigm? International Journal of Information Management. 32(4), 326-336. Available at http://dx.doi.org/10.1016/j.ijinfomgt.2012.05.006

Asian Development Bank (ADB) (2014). Asia SME Finance Monitor 2013. Manila: Asian Development Bank.

Bianchi, M, Campodall'Orto, S, Frattini, F, \& Vercesi, P. (2010). Enabling open innovation in small-and mediumsized enterprises: how to find alternative applications for your technologies. R\&D Management, 40 (4), $414-431$

Carnazza, G. (n.d). The Role and the Main Developments of MSMEs in the European Economy UEAPME STUDY UNIT MAISON DE L'ECONOMIE EUROPEENNE -RUE JACQUES DE LALAING 4 -B-1040 BRUXELLES. Available at

http://www.ueapme.com/IMG/pdf/The_role_and_the_main_developments_of_MSMEs_in_the_European_economy _without_Annex.pdf

CEDA (2016) Citizen Entrepreneurial Development Agency (CEDA). Available at http://www.ceda.co.bw/background

Chesbrough, H. W. (2006). Open innovation: A new paradigm for understanding industrial innovation. In H. W. Chesbrough, W. Vanhaverbeke \& J. West (Eds.), Open Innovation: Researching a New Paradigm (pp. 1-12). 0xford: Oxford University Press

Chimucheka, T. and Mandipaka, F. (2015). Challenges Faced By Small, Medium And Micro Enterprises in the Nkonkobe Municipality. International Business \& Economics Research Journal, Volume 14(2):309-316

Christensen, JF, Olesen, MH, \& Kjær, JS. (2005). The industrial dynamics of open innovation-evidence from the transformation of consumer electronics. Research Policy, 34(10), 1533-1549.

Colombo, MG, Piva, E, \& Rossi-Lamastra, C. (2014). Open innovation and within-industry diversification in small and medium enterprises: The case of open source software firms. Research Policy, 43(5), 891-902

Daniels, L. (1999), "The role of small enterprises in the household and national economy in Kenya: A significant contribution or a last resort". World Development, 27(1), 55 - 65

dos Santos, J.F.S .(2015) Why MSMEs are key to growth in Africa Available at https://www.weforum.org/agenda/2015/08/why-MSMEs-are-key-to-growth-in-africa/. Accessed 17 April 2017

Edinburgh Group (2012); Growing the Global Economy through MSMEs Retrieved from: http://www.edinburghgroup.org/media/2776/edinburgh_group_research_-growing_the_global_economy_through_MSMEs.pdf, 2012

European Commission (2008). SBA fact sheet Portugal. European Commission: Enterprise and Industry, European Commission Friedman, M. and Angelus H. (n.d). Best Practices in Collaborative Innovation : How Manufacturers and Retailers Can Profit from Collaborative Innovation. Kalypso White Paper. Available at 
http://viewpoints.io/uploads/files /Best_Practices_in_Collaborative_Innovation_1.pdf. Accessed on 16 May 2016

Frimpong, C. Y. (2013). MSMEs as an Engine of Social and Economic Development in Africa. Available at https://www.modernghana.com/news/478225/1/MSMEs-as-an-engine-of-social-and-economicdevelopme.html. Accessed 17 April 2017

Gassmann H, Enkel E, Chesbrough HW (2010). The future of open innovation. R\&D Management 40, 213-221.

Government of Botswana (2011). Support for Existing Small \& Medium Enterprises.

http://www.gov.bw/en/Business/Sub-audiences/Small--Medium-Businesses/Support-for-Existing-Small-Medium/. . Accessed 15 December 2016

Hossain M. (2015). A review of literature on open innovation in small and medium-sized enterprises. Journal of Global Entrepreneurship Research (2015) 5:6 DOI 10.1186/s40497-015-0022-y

IFC. (2006). Micro, Small, and Medium Enterprises: A Collection of Published Data, in Newberry, Derek, 2006. The Role of Small- and Medium-Sized enterprises in the Futures of Emerging Economies. Earth Trends 2006. World Resources Institute under a Creative Commons License.

Jefferis, K. (n.d) The New Policy on Small, Medium and Micro Enterprises: BIDPA Briefing. Available at http://dspace.africaportal.org/jspui/bitstream/123456789/31791/1/SPECIAL\%20BRIEFING\%20-

\%20SME\%20POLICY.pdf?1 Accessed 13 December 2016

LEA(2008). About Local Enterprise Authority; Gaborone.

LEA (2007). Small, Medium and Large Enterprises Database, sector mapping and validation in Botswana: Findings and Strategies for Local Enterprise Botswana.

BIDPA (2007). The role of the informal sector in Diversification of Selebi-Phikwe. Gaborone

Lee, YG, Park, SH, \& Song, YI. (2009). Which is better for a firm's financial performance: An externally oriented or inwardly oriented innovation strategy? An empirical study on Korean MSMEs. Asian Journal of Technology Innovation, 17(1), 57-73.

Lee, S, Park, G, Yoon, B, \& Park, J. (2010). Open innovation in MSMEs-An intermediated network model. Research Policy, 39(2), 290-300.

Lin J.Y. \& Lin Y.(2001). Promoting growth of medium and small-sized enterprises through the development of medium and small-sized financial institutions. Economic Research Journal, No. 1: pp.10-19

Masarira, S and Msweli, P. (2013). The Role of MSMEs in National Economies: The Case of South Africa. Economic and Social Development: Book of Proceedings; Varazdin: 1484-1494. Varazdin: Varazdin Development and Entrepreneurship Agency (VADEA).

Mead C. D. (1994), "The contribution of small enterprises to employment growth in Southern and Eastern Africa". World Development, 22 (12), 1881-1894

Ministry of Finance and Development planning (2006). CEDA young farmers Fund guidelines

Modisane (n.d). The challenges facing the development of SMMEs in Botswana. Stanbic Bank, Botswana, Gaborone. Available at

http://www.hotwireprc.com/documents/SBB\%20article_challenges\%20faced\%20by\%20SMMEs.pdf. Accessed 28 August 2016

Molelu, K. (2010). Youth success through fund. Available at http://www.gov.bw/en /Citizens/Topics /CitizenNews /YOUTH-SUCCESS-THROUGH-THE-FUND/. Accessed 15 December 2016.

Naoyuki Yoshino and Farhad Taghizadeh-Hesary (2016). Major Challenges Facing Small and Medium-sized Enterprises in Asia and Solutions for Mitigating Them. Asian Development Bank Institute Working Paper Series, No. 564 April 2016

OECD (2000) Small and Medium-sized Enterprises: Local Strength, Global Reach. Policy Brief. Available at file:///E:/Open\%20Air\%20Studies\%20_Collaborative\%20innovation/New\%20Research_Collaborative\%20innov ation/Paper+Article\%20Development/Small\%20and\%20Medium-

sized\%20enterprises_Local\%20and\%20Global.pdf

OECD (n.d). Small Businesses, Job Creation and Growth: Facts, Obstacles and Best Practices. Available at https://www.oecd.org/cfe/MSMEs/2090740.pdf 
OECD (1998). Small businesses, job creation and growth: facts, obstacles and best practices. OECD, 53 pages. Available at https://www.oecd.org/cfe/MSMEs/2090740.pdf

Parida, V, Westerberg, M, \& Frishammar, J. (2012). Inbound Open Innovation Activities in High-Tech MSMEs: The Impact on Innovation Performance. Journal of Small Business Management, 50(2), 283-309.

Pricewater house Coopers Private Limited (2011). Innovation: Changing the MSME landscape. Available at http://www.pwc.in/assets/pdfs/publications-2011/innovation-msme-2011.pdf. Accessed 17 April 2017

Rahman, H. (2010) Open innovation: Opportunities and challenges for MSMEs. In M. M. Cruz-Cunha \& J. Varajão (Eds.), E-business issues, challenges and opportunities for MSMEs: Driving Competitiveness (pp. 87-100). IGI Global

Rahman H and Ramos I. (2013). Challenges in Adopting Open Innovation Strategies in MSMEs: An Exploratory Study in Portugal. Issues in Informing Science and Information Technology, Volume 10, p. 431-448

Robu, M (2013). The Dynamic and Importance of MSMEs in Economy. The USV Annals of Economics and Public Administration, Volume 13, Issue 1(17), 84-89

Saguy, I.S. 2011. Paradigm shifts in academia and the food industry required to meet innovation challenges. Trends in Food Science \& Technology 22:467-475 doi: 10.1016/j.tifs.2011.04.003

Teirlinck, P, \& Spithoven, A. (2013). Research collaboration and R\&D outsourcing: Different R\&D personnel requirements in MSMEs. Technovation, 33(4), 142-153.

Tushman, M., \& Nadler, D. (1986). Organizing for innovation. California Management Review, 28(3), 74- 92.

Van de Vrande, V., De Jong, J. P. J., Vanhaverbeke, W., \& De Rochemont, M. (2009). Open innovation in MSMEs: Trends, motives and management challenges. Technovation, 29(6), 423-437.

WBCSD. (2007). Promoting small and medium enterprises for sustainable development. [Online] Available: http://www.wbcsd.org/Plugins/DocSearch/details.asp?DocTypeId=25\&ObjectId=MjU1MTM

Wohlmuth, K., Alabi, R. A., Burger, P., Gutowski, A., Jerome, A., Knedlik, T., Meyn, M., \& Urban, T. (2009). New Growth and Poverty Alleviation Strategies for Africa-Institutional and Local Perspectives. LIT Verlag Münster

World Economic Forum (2015) Collaborative Innovation Transforming Business, Driving Growth. Available http://www3.weforum.org/docs /WEF_Collaborative_Innovation_report_2015.pdf. Accessed 7 December 2015

Wynarczyk, P. (2014). Exploring the benefits of open innovation in MSMEs. TECH MONITOR, April_June, 2014, pp.53-54 . Available at http://www.techmonitor.net/tm/images /3/37/14apr_jun_managing_innovation.pdf

Wynarczyk, P. (2013). Open innovation in MSMEs: A dynamic approach to modern entrepreneurship in the twenty-first century. Journal of Small Business and Enterprise Development, 20(2), 258-278

Yoon B., Shin J. and Lee S. (2016). Open Innovation Projects in MSMEs as an Engine for Sustainable Growth. Sustainability, 8, 146:1-27 